\title{
Plasma Hepcidin Correlates Positively With Interleukin-6 in Patients Undergoing Pulmonary Endarterectomy
}

\author{
P. MARUNA ${ }^{1}$, M. VOKURKA ${ }^{1}$, J. LINDNER $^{2}$ \\ ${ }^{1}$ Institute of Pathological Physiology, and ${ }^{2}$ Second Department of Surgery - Department of \\ Cardiovascular Surgery, First Faculty of Medicine, Charles University in Prague and General \\ Teaching Hospital in Prague, Prague, Czech Republic
}

Received March 27, 2010

Accepted November 19, 2010

On-line March 14, 2011

\section{Summary}

Hepcidin, a recently discovered antimicrobial peptide synthesized in the liver, was identified to be the key mediator of iron metabolism and distribution. Despite our knowledge of hepcidin increased in recent years, there are only limited data on hepcidin regulation during systemic inflammatory response in human subjects. In a prospective study, the time course of plasma hepcidin was analyzed in relations to six inflammatory parameters - plasma cytokines and acute-phase proteins in patients undergoing uncomplicated pulmonary endarterectomy. Twenty-four patients (males, aged 52.6 \pm 10.2 years, treated with pulmonary endarterectomy in a deep hypothermic circulatory arrest) were enrolled into study. Hepcidin, interleukin (IL)-6, IL8 , tumor necrosis factor- $a, C$-reactive protein, $a_{1}$-antitrypsin and ceruloplasmin arterial concentrations were measured before surgery and repeatedly within $120 \mathrm{~h}$ post-operatively. Hemodynamic parameters, hematocrit and markers of iron metabolism were followed up. In a postoperative period, hepcidin increased from preoperative level $8.9 \mathrm{ng} / \mathrm{ml}$ (6.2-10.7) (median and interquartile range) to maximum $16.4 \mathrm{ng} / \mathrm{ml}$ (14.1-18.7) measured $72 \mathrm{~h}$ after the end of surgery. Maximum post-operative concentrations of hepcidin correlated positively with maximum IL- 6 levels. Both hepcidin and IL- 6 maximum concentrations correlated positively with extracorporeal circulation time. In conclusions, the study demonstrated that plasma hepcidin is a positive acute-phase reactant in relation to an uncomplicated large cardiac surgery. Hepcidin increase was related to IL-6 concentrations and to the duration of surgical procedure. Our clinical findings are in conformity with recent experimental studies defining hepcidin as a type II acute-phase protein.

\section{Key words}

C-reactive protein - Cardiac surgery - Cytokines - Hepcidin • Interleukin-6

\section{Corresponding author}

Pavel Maruna, Institute of Pathological Physiology, First Faculty of Medicine, Charles University in Prague, U Nemocnice 5, 12808 Prague 2, Czech Republic. Fax: +420 224919780. E-mail: maruna@lf1.cuni.cz

\section{Introduction}

Hepcidin is small cystein-rich peptide produced mainly in the liver. First described as a 25 -amino acid (aa) antimicrobial peptide (hepatic bactericidal protein) (Park et al. 2001), it was subsequently found to be a powerful negative regulator of iron absorption. Hepcidin is a key regulator of iron metabolism playing an important role in the pathogenesis of anemia of chronic disease (Ganz 2006). It has a crucial role in the pathogenesis of hemochromatosis and related disorders (Papanikolaou et al. 2005).

Human hepcidin is produced from a 54-aa precursor including a putative 24 -aa signal peptide. The early studies showed that hypoxia, iron, and inflammation influence hepcidin levels, but the exact mechanism remained elusive (Nicolas et al. 2002, Krijt et al. 2009). The synthesis is up-regulated in intact animals by the injection of lipopolysaccharide (endotoxin) and interleukin (IL)-6 although a direct stimulating effect of other cytokines as IL- $1 \alpha$, and IL- $1 \beta$ was confirmed in in vitro studies (Lee et al. 2005). Due to dominant 
regulation by IL-6, hepcidin was classified as a type II acute-phase protein (Nemeth et al. 2003).

Despite our knowledge of hepcidin regulation and activities increased considerably in recent years, there are only limited data on hepcidin in human subjects, and much of findings come from animal and in vitro models. While quantitative methods have been used for the determination of serum prohepcidin, the technical problems prevented reliable and routine measurements of active 25-aa hepcidin in plasma until 2009.

Authors of the present study used a specific group of cardiosurgical patients undergoing pulmonary endarterectomy (PEA) in a deep hypothermic circulatory arrest (DHCA). PEA represents as a model of cytokine network hyperstimulation and intensive time-limited noninfectious inflammatory reaction. Our previous studies (Maruna et al. 2008, Maruna et al. 2009) as well as other authors (Langer et al. 2004, Martínez Rosas 2006) reported that PEA - as a large cardiac surgery - leads to a more pronounced activation of cytokines than other surgical procedures. This cytokine 'burst' mediates a systemic response by the body's inflammatory system, well known as the systemic inflammatory response syndrome. PEA is a potential curative treatment method for patients with chronic thromboembolic pulmonary hypertension (CTEPH). PEA provides a significant survival advantage, compared to the natural prognosis of CTEPH (Roscoe and Klein 2008). At the other side the postoperative course after PEA is accompanied by a number of specific complications, which need the prolonged care in Intensive Care Units and also contribute to the high rate of early postoperative mortality, which ranges from 5 to $23 \%$. The kinetics of main pro-inflammatory cytokines after PEA were described by Lindner et al. (2009) showing the relations of cytokine network to hemodynamic disturbances postsurgery.

In a prospective study, the time course of plasma hepcidin was analyzed in relations to six inflammatory parameters - plasma cytokines and acute-phase proteins in patients undergoing uncomplicated PEA in DHCA. Respecting gender differences in hepcidin basal concentrations with significantly higher levels in men (Grebenchtchikov et al. 2009), only male patients were included into our study.

Authors hypothesized that post-surgery changes of plasma hepcidin concentrations would be responding to dynamics of other acute-phase proteins and related to IL-6 or other main inflammatory cytokines development.

\section{Material and Methods}

A prospective study was approved by local research and ethics committee and a written informed consent was obtained from the subjects. Male patients with CTEPH scheduled for isolated PEA on the Second Department of Surgery - Department of Cardiovascular Surgery, General Faculty Hospital in Prague were enrolled into study between January 2008 and August 2010. Exclusion criteria were the combination of PEA with other surgical procedure, postoperative bleeding, thromboembolic complication, local and systemic infection, defined according to guidelines of the Center for Disease Control and Prevention (Horan and Gaynes 2004).

\section{Surgical procedure}

The standard approach for PEA was median sternotomy. Cardio-pulmonary bypass (CPB) was established with cannulation of the ascending aorta and the inferior and superior vena cava. Deep hypothermic circulatory arrest (DHCA, $18-20{ }^{\circ} \mathrm{C}$ ) was used to ensure optimum operating conditions and facilitate accurate endarterectomty by infusion of crystalloid cardioplegic solution (Custodiol, Kohler Chemie, Germany). Approach to the right pulmonary artery was established after mobilization of vena cava within the pericardium. Endarterectomy was started with dissection in right level of pulmonary artery and followed to the segmental branches. To achieve accurate visualization during peripheral dissection, repeated periods of DHCA limited to $20 \mathrm{~min}$ were performed with reestablishment of CPB between them. Arteriotomy on the main pulmonary artery was started on the left side and continued to the left branch. After completion of endarterectomy on the both sides, CPB was recommenced along with controlled rewarming. Weaning from CPR was started with pressure control ventilation with positive end-expiratory pressure (PEEP), atrio-ventricular epicardial stimulation, stepwise increased filling of the right heart and reduction of pump flow together with low doses of norepinephrine targeted to reach mean pulmonary artery pressure (MPAP) less than $20 \mathrm{~mm} \mathrm{Hg}$, mean artery pressure (MAP) over $70 \mathrm{~mm}$ $\mathrm{Hg}$, normooxemia and normocapnea. Dobutamine (Dobutrex, Lily, Germany) was administered only if inotropic support was needed during or after weaning of $\mathrm{CPB}$. Before the end of CPB, we used an ultra filtration for hemoconcentration. 


\section{Monitoring}

Radial and femoral artery cannulae, triple lumen central venous cannula, Swan-Ganz catheter, and single lumen jugular bulb catheter were inserted for continuous monitoring of hemodynamic parameters and jugular bulb blood saturation. Left atrial catheter was surgically placed for both measurement and norepinephrine administration.

\section{Blood sample collection}

Arterial blood samples were drawn from femoral artery catheter before operation, after sternotomy, after DHCA, after separation from CPB, then 12, 18, 24, 36, 48, 72, and $120 \mathrm{~h}$ after separation from CPB. For all measurements, $5 \mathrm{ml}$ of arterial blood was drawn into a vacutainer heparin tube and immediately centrifuged at $5000 \mathrm{rpm}$ for $15 \mathrm{~min}$. Plasma was stored at $-80{ }^{\circ} \mathrm{C}$ until analysis.

\section{Hepcidin, cytokines and acute-phase proteins analysis}

Plasma hepcidin concentration was measured by enzyme-linked immunoassay using a commercially available kit (DRG Diagnostics, Marburg, Germany) in duplicates - the analytical sensitivity of the assay was $0.9 \mathrm{ng} / \mathrm{ml}$, intra-assay coefficients of variation (CV) calculated by DRG Diagnostics was below $5 \%$, interassay precision was $11 \%(6.0 \mathrm{ng} / \mathrm{ml})$ and $10 \%(15.8$ $\mathrm{ng} / \mathrm{ml})$. Plasma concentrations of tumor necrosis factor (TNF) $\alpha$, IL-6, IL-8 (ELISA, Immunotech, Paris, France), C-reactive protein (CRP) (Kryptor - TRACE technology, ultrasensitive analysis, BRAHMS AG, Hennigsdorf, Germany), $\alpha_{1}$-antitrypsin (AAT), and ceruloplasmin (CPL) (nephelometry, BRAHMS AG, Hennigsdorf, Germany) were measured in duplicates, too. The intraand inter-assay $\mathrm{CV}$ were below $5 \%$.

\section{Hemodynamic parameters}

Mean pulmonary artery pressure (MPAP), cardiac index (CI), pulmonary vascular resistance (PVR), and ejection fraction (EF) were followed. The time of norepinephrine support was recorded in all patients.

Plasma iron (colorimetric analysis, PlivaLachema a.s., Brno, Czech Republic), ferritin, and transferrin (immunoturbidimetry, Dialab Gmbh, Wr. Neudorf, Austria) were examined preoperatively and repeatedly within $120 \mathrm{~h}$ after the end of surgery.

\section{Statistical analysis}

Statistical analysis was carried out using SPSS software (version 12.0) for Windows (SPSS, Chicago,
USA). The normal distribution of all data was examined using the Kolmogorov-Smirnov normality test to determine subsequent use of tests for statistical comparison. As variables were not normally distributed, the data were reported as medians and interquartile range. Bonferroni correction (multiple-comparison correction) was used to analyze simultaneous measurement at different time points. The Pearson's correlation coefficient and the Spearman's rank correlation evaluated correlation between the indicators. For all the tests, $\mathrm{p}<0.05$ was defined as statistically significant.

Table 1. Preoperative data.

$\begin{array}{ll}\text { Number of patients (males) } & 24 \\ \text { Age (years) } & 52.6 \pm 10.2 \\ \text { Preoperative New York Heart } & 3.4 \pm 0.4 \\ \text { Association (NYHA) classification } & \\ \text { Mean pulmonary artery pressure } & 53.1 \pm 7.2 \\ \text { (mm Hg) } & \end{array}$

Variables mean \pm standard deviation.

\section{Results}

Twenty-four patients were enrolled during the 32 months of the trial (Table 1). All patients underwent satisfactory clearance of intra-arterial obstruction, and there were no intra-operative deaths. No patients required allogenic blood transfusion. Operative and basic hemodynamic data are given in Table 2. There was considerable improvement in hemodynamic variables post-surgery. PEA significantly decreased mPAP and pulmonary vascular resistance.

No significant correlation was revealed between plasma hepcidin and IL-6 concentrations preoperatively as well as between hepcidin and other tested inflammatory markers, hemodynamic values, plasma iron, transferrin and ferritin before surgery.

An uncomplicated course after PEA was associated with a transient initial decline of hepcidin and subsequent elevation (Fig. 1). Minimal hepcidin concentrations were found in blood samples collected after the last DHCA. Initial decline of hepcidin appeared to correlate with the decreased hematocrit due to hemodilution on CPB $(\mathrm{r}=0.84, \mathrm{p}=0.003)$. During perioperative period, hepcidin increased from preoperative level $8.9 \mathrm{ng} / \mathrm{ml}$ (6.2-10.7) (median and interquartile range) to maximum $16.4 \mathrm{ng} / \mathrm{ml}(14.1-18.7)$ 


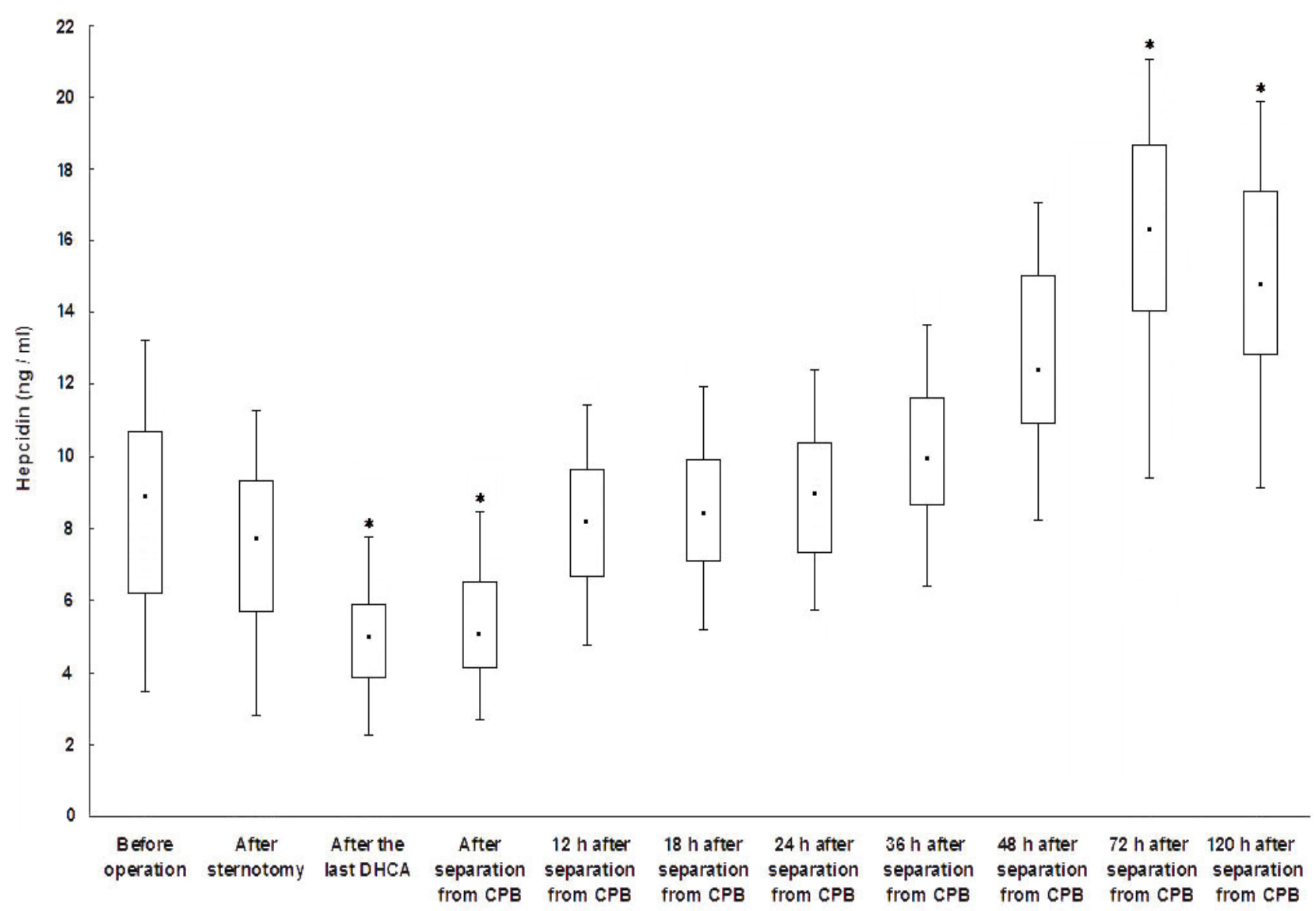

Fig. 1. Hepcidin plasma concentrations in perioperative period. Box and whisker plot depicting the median values, interquartile range and full range. $*$ Statistically significant differences $(p<0.05)$ to preoperative value.

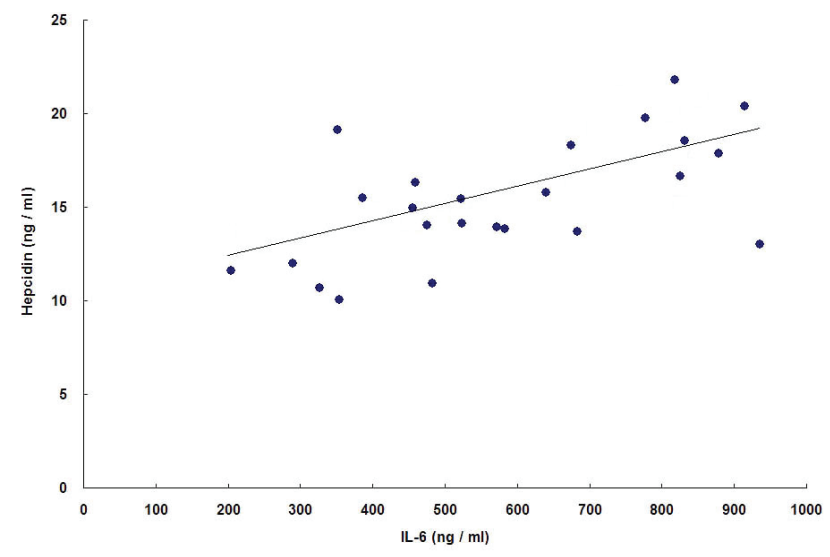

Fig. 2. Correlation between maximum hepcidin and IL-6 concentrations post-surgery $(r=0.693, p=0.025)$.

measured $72 \mathrm{~h}$ after the end of surgery (e.g., separation from CPB). After it, the levels started declining but were still higher than pre-operatively until $120 \mathrm{~h}$ after the end of surgery.

IL-6, IL-8, and TNF $\alpha$ initial decline with minimum levels after the last DHCA was related to hemodilution and cleared after correction to hematocrit. IL-6 and TNF $\alpha$ culminated $12 \mathrm{~h}$ after separation from CPB (Table 3). IL-8 levels reached maximum in samples collected $18 \mathrm{~h}$ after separation from CPB. CRP showed prolonged elevation to maximum $48 \mathrm{~h}$ after the end of surgery. The same dynamics was found in AAT. CPL increase was delayed in relation to other tested acutephase proteins reaching maximal levels $72 \mathrm{~h}$ after separation from CPB. Postoperative peak values of IL-6 and TNF $\alpha$ correlated closely $(\mathrm{r}=0.86, \mathrm{p}<0.01)$, as well as peak values of IL-6 and IL-8 $(r=0.79, \mathrm{p}<0.01)$.

Maximum post-operative concentrations of hepcidin measured $72 \mathrm{~h}$ after a separation from CPB correlated positively with maximum IL-6 levels achieved $12 \mathrm{~h}$ after the end of surgery $(\mathrm{r}=0.69, \mathrm{p}=0.025)$ (Fig. 2 ) as well as with IL-6 levels measured $18 \mathrm{~h}(\mathrm{r}=0.64, \mathrm{p}=0.036)$ and $24 \mathrm{~h}$ after the end of surgery $(\mathrm{r}=0.61, \mathrm{p}=0.043)$. Similarly hepcidin and CRP concentrations correlated significantly $72 \mathrm{~h}$ after the end of surgery $(\mathrm{r}=0.62$, $\mathrm{p}=0.049$ ). No other tested inflammatory parameter correlated significantly with hepcidin post-surgery. 
Table 2. Operative and hemodynamic data.

$\begin{array}{lll}\text { Duration of CPB (min) } & & 332.1 \pm 55.9 \\ \text { Cross clamp time (min) } & & 129.6 \pm 18.0 \\ \text { DHCA time (min) } & & 46.1 \pm 6.3 \\ \text { Minimum temperature }\left({ }^{\circ} \mathrm{C}\right) & 17.2 \pm 0.8 \\ \text { Ejection fraction (\%) } & \text { preoperatively } & 59.3 \pm 7.4 \\ \text { Mean pulmonary artery pressure }(\mathrm{mm} \mathrm{Hg}) & \text { preoperatively } & 53.8 \pm 7.4 \\ & \text { postoperatively } & 24.2 \pm 7.3 \\ \text { Cardiac index }\left(\text { l.min }^{-1} \mathrm{~m}^{-2}\right) & \text { preoperatively } & 1.93 \pm 0.42 \\ & \text { postoperatively } & 2.96 \pm 0.44 \\ \text { Pulmonary vascular resistance }(\text { dynes.s.cm } & -5 & 1138.2 \pm 321.3 \\ & \text { preoperatively } & 212.3 \pm 96.8\end{array}$

Variables are means \pm standard deviation. Postoperative data are given $24 \mathrm{~h}$ after admission to intensive care unit. DHCA - deep hypothermic circulatory arrest, CPB - cardiopulmonary bypass.

Table 3. Cytokines and acute phase proteins in perioperative period.

\begin{tabular}{|c|c|c|c|c|c|c|}
\hline Time & $\begin{array}{l}\text { IL-6 } \\
(\mathrm{ng} / \mathrm{l})\end{array}$ & $\begin{array}{l}\text { IL-8 } \\
(\mathrm{ng} / \mathrm{l})\end{array}$ & $\begin{array}{l}\text { TNFa } \\
\text { (ng/l) }\end{array}$ & $\begin{array}{l}\text { CRP } \\
(\mathrm{mg} / \mathrm{l})\end{array}$ & $\begin{array}{l}\text { AAT } \\
\text { g/l) }\end{array}$ & $\begin{array}{l}\text { CPL } \\
(\mathrm{g} / \mathrm{l})\end{array}$ \\
\hline Before sternotomy & $\begin{array}{c}30 \\
(18-44)\end{array}$ & $\begin{array}{c}43 \\
(18-96)\end{array}$ & $\begin{array}{c}14 \\
(8-44)\end{array}$ & $\begin{array}{c}4.7 \\
(1.7-13.5)\end{array}$ & $\begin{array}{c}1.3 \\
(0.7-1.9)\end{array}$ & $\begin{array}{c}0.16 \\
(0.07-0.25)\end{array}$ \\
\hline $\begin{array}{l}12 \text { h after separation } \\
\text { from } C P B\end{array}$ & $\begin{array}{c}586 * \\
(354-849)\end{array}$ & $\begin{array}{c}432 * \\
(256-674)\end{array}$ & $\begin{array}{c}234 * \\
(147-465)\end{array}$ & $\begin{array}{c}3.0 \\
(1.1-9.7)\end{array}$ & $\begin{array}{c}1.3 \\
(0.8-1.9)\end{array}$ & $\begin{array}{c}0.18 \\
(0.12-0.28)\end{array}$ \\
\hline $\begin{array}{l}18 \text { h after separation } \\
\text { from } C P B\end{array}$ & $\begin{array}{c}135 * \\
(101-226)\end{array}$ & $\begin{array}{c}474 * \\
(285-629)\end{array}$ & $\begin{array}{c}146 * \\
(79-264)\end{array}$ & $\begin{array}{c}9.0 \\
(4.3-12.6)\end{array}$ & $\begin{array}{c}1.9 \\
(1.2-2.6)\end{array}$ & $\begin{array}{c}0.21 \\
(0.14-0.31)\end{array}$ \\
\hline $\begin{array}{l}24 \text { h after separation } \\
\text { from } C P B\end{array}$ & $\begin{array}{c}97 * \\
(74-126)\end{array}$ & $\begin{array}{c}321 * \\
(203-453)\end{array}$ & $\begin{array}{c}127 * \\
(56-184)\end{array}$ & $\begin{array}{c}34.3 * \\
(21.4-43.9)\end{array}$ & $\begin{array}{c}2.7 * \\
(1.3-3.1)\end{array}$ & $\begin{array}{c}0.29 * \\
(0.18-0.38)\end{array}$ \\
\hline $\begin{array}{l}36 \text { h after separation } \\
\text { from } C P B\end{array}$ & $\begin{array}{c}74 * \\
(46-95)\end{array}$ & $\begin{array}{c}242 * \\
(134-379)\end{array}$ & $\begin{array}{c}54^{*} \\
(27-84)\end{array}$ & $\begin{array}{c}62.4 * \\
(43.1-84.6)\end{array}$ & $\begin{array}{c}2.9 * \\
(1.6-3.6)\end{array}$ & $\begin{array}{c}0.34 * \\
(0.26-0.46)\end{array}$ \\
\hline $\begin{array}{l}48 \text { h after separation } \\
\text { from } C P B\end{array}$ & $\begin{array}{c}44 \\
(23-71)\end{array}$ & $\begin{array}{c}170 * \\
(97-245)\end{array}$ & $\begin{array}{c}29 \\
(18-54)\end{array}$ & $\begin{array}{c}79.2 * \\
(44.9-98.0)\end{array}$ & $\begin{array}{c}3.0 * \\
(2.3-3.7)\end{array}$ & $\begin{array}{c}0.38 * \\
(0.28-0.49)\end{array}$ \\
\hline $\begin{array}{l}72 \text { h after separation } \\
\text { from } C P B\end{array}$ & $\begin{array}{c}36 \\
(22-54)\end{array}$ & $\begin{array}{c}62 \\
(32-109)\end{array}$ & $\begin{array}{c}21 \\
(9-46)\end{array}$ & $\begin{array}{c}47.5 * \\
(36.1-67.2)\end{array}$ & $\begin{array}{c}2.4 * \\
(1.6-3.2)\end{array}$ & $\begin{array}{c}0.44 * \\
(0.30-0.57)\end{array}$ \\
\hline
\end{tabular}

Variables are medians (interquartile range). ${ }^{*}$ Statistically significant differences to preoperative values on $p<0.05$. AAT $-a_{1}$-antitrypsin; $\mathrm{CPL}$ - ceruloplasmin; CRP - $\mathrm{C}$ reactive protein; $\mathrm{IL}$ - interleukin; $\mathrm{TNFa} \mathrm{-} \mathrm{tumor} \mathrm{necrosis} \mathrm{factor} \mathrm{a}$

Both hepcidin and IL-6 maximum concentrations correlated positively with ECC time $(\mathrm{p}=0.043, \mathrm{p}=0.027$ respectively). Hepcidin evolution post-surgery was not significantly related to CI, MPAP, PVR and EF. Among inflammatory markers, IL-6 plasma concentrations correlated inversely with $\mathrm{CI}$ at the time of separation from CPB $(\mathrm{k}=-0.650, \mathrm{p}=0.026)$. Similarly IL-8 concentrations correlated significantly with $\mathrm{CI}$ at the same time $(\mathrm{k}=-0.636, \mathrm{p}=0.017)$. No significant relation was found between postoperative cytokine levels and
MPAP or PVR.

$48 \mathrm{~h}$ postoperatively, there was a significant decrease in serum iron concentration (Table 4). Ferritin concentrations increased postoperatively reaching maximum levels $36 \mathrm{~h}$ after the end of surgery and stayed elevated until $120 \mathrm{~h}$ post-surgery. Correlation between hepcidin and ferritin $72 \mathrm{~h}$ post-surgery $(\mathrm{p}=0.057)$ did not achieve a statistical significance. Multifactorial analysis did not reveal significant correlation between hepcidin and iron, resp. hepcidin and transferrin within a 120-h 
Table 4. Plasma iron, ferritin and transferrin in perioperative period.

\begin{tabular}{|c|c|c|c|}
\hline Time & $\begin{array}{c}\text { Iron } \\
(\mu \mathrm{mol} / \mathrm{l})\end{array}$ & $\begin{array}{c}\text { Ferritin } \\
(\mu \mathrm{g} / \mathrm{l})\end{array}$ & $\begin{array}{c}\text { Transferrin } \\
(\mathrm{g} / \mathrm{l})\end{array}$ \\
\hline Before sternotomy & $\begin{array}{c}19.4 \\
(12.8-24.9)\end{array}$ & $\begin{array}{c}56.2 \\
(29.2-94.0)\end{array}$ & $\begin{array}{c}2.2 \\
(1.7-2.7)\end{array}$ \\
\hline $\begin{array}{l}12 \text { h after separation } \\
\text { from } C P B\end{array}$ & $\begin{array}{c}11.3 * \\
(5.4-17.3)\end{array}$ & $\begin{array}{c}39.1 * \\
(18.2-68.7)\end{array}$ & $\begin{array}{c}1.6 * \\
(0.9-2.1)\end{array}$ \\
\hline 18 h after separation & $13.9 *$ & 52.3 & 1.9 \\
\hline from $C P B$ & $(7.2-16.8)$ & $(22.6-76.3)$ & $(1.3-2.4)$ \\
\hline 24 h after separation & 17.6 & 96.3 & 1.9 \\
\hline from $C P B$ & $(13.7-21.3)$ & $(64.7-144.2)$ & $(1.4-2.6)$ \\
\hline 36 h after separation & 14.2 & $132.5 *$ & $1.7 *$ \\
\hline from $C P B$ & $(11.7-18.4)$ & $(59.4-176.3)$ & $(1.1-2.4)$ \\
\hline $48 \mathrm{~h}$ after separation & $11.0 *$ & $126.4 *$ & $1.6 *$ \\
\hline from $C P B$ & $(6.9-14.6)$ & $(64.5-173.8)$ & $(0.9-2.1)$ \\
\hline 72 h after separation & $12.3 *$ & $116.2 *$ & 2.0 \\
\hline from $C P B$ & $(7.4-19.4)$ & $(63.1-147.0)$ & $(1.6-2.7)$ \\
\hline
\end{tabular}

Variables are medians (interquartile range). ${ }^{*}$ Statistically significant differences $(p<0.05)$ to preoperative values.

time frame after a separation from CPB. Similarly, no significant correlation was found between hepcidin and plasma activities of alanine aminotransferase or aspartate aminotransferase post-surgery.

Significant correlation was revealed between perioperative norepinephrine support (expressed as a time period in hours) and IL-6 plasma concentrations at the time of separation from CPB $(\mathrm{k}=0.736, \mathrm{p}=0.004)$ and $12 \mathrm{~h}$ after $(\mathrm{k}=0.798, \mathrm{p}=0.004)$. Individual maximum doses of norepinephrine during PEA were compared with cytokine, hepcidin and other acute-phase protein levels in the same period, however without statistical significance for any of the inflammatory parameters.

\section{Discussion}

In the study, authors report a significant alteration of plasma hepcidin in patients undergoing a large cardiac surgery. Hepcidin concentrations increased post-operatively reaching a maximum $72 \mathrm{~h}$ after the separation from CPB. In a homogenous group of uncomplicated surgical patients, significant correlation between hepcidin and IL-6 concentrations post-surgery was observed.

Nine years after discovery of hepcidin, our work is the first clinical study evaluating early post-operative changes of plasma hepcidin on a larger group of patients.
Several months ago, Hoppe et al. (2009) reported first results of hepcidin in 5 male patients undergoing heart surgery. On a limited number of patients, authors found a significant increase in serum hepcidin within a 144-h time frame.

Hepcidin is predominantly expressed in the liver. Expression as studied on mRNA level is also detectable in other tissues (heart, kidney, adipose tissue, pancreas and haematopoietic cells), although the biological relevance of extra-hepatic hepcidin is not well defined yet. Recently, Vokurka et al. (2009) described the increase of hepcidin mRNA expression in the subcutaneous adipose tissue during the major elective cardiac surgery, however the total plasma hepcidin concentration was not measured. Hepcidin was demonstrated to be up-regulated by the inflammatory cytokines IL-1 $\alpha$, IL1- $\beta$, and IL-6. The activity of erythropoiesis rather than simple anemia was postulated later as an important regulatory factor (Vokurka et al. 2006). Recent studies brought new data about molecular pathways of the regulation of hepcidin gene through these different stimuli. An increased number of animal and in vitro models gave evidence that the regulation of hepcidin is a complex signaling network (reviewed by Kemna et al. 2008, Zhang and Enns 2009). Inflammation increases hepcidin expression. The inflammatory changes of hepcidin are supposed to control iron availability for 
microorganisms during the infection, however they contribute to iron-restricted erythropoiesis in anemia of chronic disease (Weiss and Goodnough 2005). Different research groups discovered that IL-6, through the Jak/STAT-3 signaling pathway, is involved in regulation of hepcidin levels in response to inflammatory stimuli (Wrighting and Andrews 2006, Truksa et al. 2007). Considering a dominant regulation by IL-6, hepcidin was classified as a type II acute-phase protein (Nemeth et al. 2003). A second mode of hepcidin regulation depends upon signaling through the bone morphogenetic protein/Smad (BMP/Smad) pathway. Babitt et al. (2007) showed that mice with a deletion in the Smad4 gene were unable to synthesize hepcidin in response to inflammatory stimuli or to iron load.

Technical problems prevented reliable and routine measurements of plasma hepcidin until 2009. Several factors, including the small size and the compact structure of the peptide, the high degree of conservation between species, and the limited availability of the antigen, hampered development of proper immunochemical methods (Piperno et al. 2009). Substantial piece of clinical results come from the measurement of prohepcidin but its biological relevance and relation to hepcidin remain unclear (Frazer and Anderson 2009). Hepcidin was measured in serum or urine mainly by the method developed by Ganz (2008) and by various modifications of mass spectrometry (Swinkels et al. 2008). However, it is so far impossible to establish relevant physiological interval of hepcidin serum concentration. Recent study compared the different method of hepcidin measurements. The methods used for hepcidin measurement comprise mass spectrometry (SELDI-TOF MS, MALDI-TOF MS, LC-MS/MS, ICTOF-MS) and immunochemical assays (competitive ELISA or RIA) which were developed in several laboratories and companies. So far, no standard and reference method is available. The comparison of methods shows different absolute values but similar relative differences. However, MS-based methods might be superior in detecting only bioactive hepcidin- 25 and distinguishing other isoforms. This may be valuable mainly in situations with variable presence of hepcidin isoforms like in chronic kidney disease (Kroot et al. 2009, Kroot et al. 2010).

In the human studies reported to date, increased hepcidin production and increased urinary excretion of hepcidin have been noted among patients with infections, malignancy, chronic kidney disease or inflammatory states. Nevertheless, further studies are needed to clarify this issue and the role of inflammatory, erythropoietic and iron regulatory pathways in hepcidin synthesis in human pathology.

Uncomplicated surgery induces a cytokine response characteristic of inflammation. An early and transient induction of TNF $\alpha$ and IL-1 $\beta$ is followed by an increase in IL-6 and other cytokines creating the complete laboratory and clinical image of an acute-phase response. Actually about 20 cytokines are known to stimulate acute-phase protein synthesis in liver but an essential role of IL-6 in this action is out of doubt.

Our observation of hepcidin as a positive acutephase reactant in an early post-surgery period conforms to the recent report of Hoppe et al. (2009). Nonetheless we observed a significant relationship between hepcidin and IL-6 postoperatively which did previous authors not find. Both the small sample size and an involvement of two surgical procedures into study by Hoppe et al. limit the comparison of results. In our patients, maximum postsurgery concentrations of hepcidin correlated positively with maximum IL-6 levels. Both hepcidin and IL-6 evolution was related to ECC time. These findings indicate possible links between an intensity of initial stress stimulus and the amplitude of hepcidin response, most likely mediated via IL-6 and/or other cytokines.

Our study demonstrates the induction of hypoferremia due to the postoperative acute-phase reaction. The finding has already been reported by Benedict et al. (2007), Hoppe et al. (2009) and other authors. The role of IL- 6 / hepcidin axis in post-surgery hypoferremia is not fully understood, yet. IL-6 infusion in human volunteers induced hepcidin and hypoferremia (Nemeth et al. 2004). IL-6 knockout mice injected with turpentine failed to develop hypoferremia. In our patients, hepcidin and IL-6 failed to correlate with parameters of iron metabolism postoperatively suggesting the role of other factors influencing iron metabolism in this period.

The main limitation of the study arises from a complexity of surgery stress response comprising different agonistic and antagonistic factors as a surgery trauma, anesthesia, ECC, hemodilution, diet restriction and medication. The effect of hemodilution on cytokine and acute phase protein concentrations during PEA was well described in our previous study (Maruna et al. 2008) and cleared after correction of cytokine concentrations to hematocrit. None of the subjects received allogenic blood transfusion. To achieve a maximal homogeneity of a group, patients with complicated postoperative course as 
well as the patient with combined procedures (PEA with maze or PEA with coronary artery bypass grafting) were excluded from the study. So far, no studies of drug liver metabolism on hepcidin expression and levels have been published. Some drugs, like erythropoietin and possibly anti-inflammatory treatment, influence hepcidin expression indirectly due to their impact on hepcidin regulation (erythropoiesis, inflammation). Nevertheless there is no information that drugs, which are routinely used in uncomplicated perioperative period after PEA, influence hepcidin synthesis.

In summary, our study demonstrated plasma hepcidin as a positive acute-phase reactant in relation to an uncomplicated large cardiac surgery. Hepcidin increase was related to IL-6 concentrations and to duration of surgical procedure. Our clinical findings are in conformity with recent experimental studies defining hepcidin as a type II acute-phase protein.

\section{Conflict of Interest}

There is no conflict of interest.

\section{Acknowledgements}

Supported with a grant MSM0021620819 of the Ministry of Education, Czech Republic.

\section{Abbreviations}

AAT

BMP

CPB

$\alpha 1$-antitrypsin

Bone morphogenetic protein

Cardio-pulmonary bypass

$\begin{array}{ll}\text { CPL } & \text { Ceruloplasmin } \\ \text { CRP } & \text { C-reactive protein } \\ \text { CTEPH } & \text { Chronic thromboembolic pulmonary } \\ & \text { hypertension } \\ \text { CV } & \text { Coefficients of variation } \\ \text { DHCA } & \text { Deep hypothermic circulatory arrest } \\ \text { ECC } & \text { Extracorporeal circulation } \\ \text { EF } & \text { Ejection fraction } \\ \text { IC-TOF-MS } & \text { Immunocapture time-of-flight mass- } \\ & \text { spectrometry } \\ \text { IL } & \text { Interleukin } \\ \text { LC-MS/MS } & \text { Liquid chromatography tandem-MS } \\ & \text { techniques }\end{array}$

MALDI-TOF MS Matrix assisted laser desorption/ionization time-of-flight mass spectrometry

MAP Mean artery pressure

MPAP Mean pulmonary artery pressure

MS Mass spectrometry

PEA Pulmonary endarterectomy

PEEP Positive end-expiratory pressure

PVR Pulmonary vascular resistance

SELDI-TOF MS Surface enhanced laser desorption/ionization time-of-flight mass spectrometry

SIRS Systemic inflammatory response syndrome

SPSS Statistical package for social sciences

TNF $\alpha \quad$ Tumor necrosis factor $\alpha$

\section{References}

BABITT JL, HUANG FW, XIA Y, SIDIS Y, ANDREWS NC, LIN HY: Modulation of bone morphogenetic protein signaling in vivo regulates systemic iron balance. J Clin Invest 117: 1933-1939, 2007.

BENEDICT C, GHIO AJ, GEHRING H, SCHULTES B, PETERS A, OLTMANNS KM: Transient hypoxia and downregulation of circulating prohepcidin concentrations in healthy young men. Haematologica 92: 125-126, 2007.

FRAZER DM, ANDERSON DJ: Hepcidin compared with prohepcidin. Am J Clin Nutr 89: 475-476, 2009.

GANZ T: Hepcidin and its role in regulating systemic iron metabolism. Hematology Am Soc Hematol Educ Program 29-35, 2006.

GANZ T: Immunoassay for human serum hepcidin. Blood 112: 4292-4297, 2008.

GREBENCHTCHIKOV N, GEURTS-MOESPOT AJ, KROOT JJC, DEN HEIJER M, TJALSMA H, SWINKELS DW, SWEEP FGJ: High-sensitive radioimmunoassay for human serum hepcidin. Brit J Haematol 146: 317-325, 2009.

HOPPE M, LÖNNERDAL B, HOSSAIN B, OLSSON S, NILSSON F, LUNDBERG PA, RÖDJER S, HULTHÉN L: Hepcidin, interleukin-6 and hematological iron markers in males before and after heart surgery. Nutr Biochem 20: 11-16, 2009. 
HORAN TC, GAYNES RP: Surveillance of nosocomial infections. Appendix A: CDC definitions of nosocomial infections. In: Hospital Epidemiology and Infection Control, MAYAHALL CG (ed), Lippincot, Williams and Wilkins, Philadelphia, 2004, pp 1659-1702.

KEMNA EH, KARTIKASARI AE, VAN TITS LJ, PICKKERS P, TJALSMA H, SWINKELS DW: Regulation of hepcidin: insights from biochemical analyses on human serum samples. Blood Cells Mol Dis 40: 339-346, 2008.

KRIJT J, FUJIKURA Y, ŠEFC L, VOKURKA M, HLOBEŇOVÁ T, NEČAS E: Hepcidin downregulation by repeated bleeding is not mediated by soluble hemojuvelin. Physiol Res 59: 53-59, 2010.

KROOT JJ, KEMNA EH, BANSAL SS, BUSBRIDGE M, CAMPOSTRINI N, GIRELLI D, HIDER RC, KOLIARAKI V, MAMALAKI A, OLBINA G, TOMOSUGI N, TSELEPIS C, WARD DG, GANZ T, HENDRIKS JC, SWINKELS DW: Results of the first international round robin for the quantification of urinary and plasma hepcidin assays: need for standardization. Haematologica 94: 1748-1752, 2009.

KROOT JJ, LAARAKKERS CM, GEURTS-MOESPOT AJ, GREBENCHTCHIKOV N, PICKKERS P, VAN EDE AE, PETERS HP, VAN DONGEN-LASES E, WETZELS JF, SWEEP FC, TJALSMA H, SWINKELS DW: Immunochemical and mass-spectrometry-based serum hepcidin assays for iron metabolism disorders. Clin Chem 56: 1570-1579, 2010.

LANGER F, SCHRAMM R, BAUER M, TSCHOLL D, KUNIHARA T, SCHAFERS HJ: Cytokine response to pulmonary thromboendarterectomy. Chest 126: 135-141, 2004.

LEE P, PENG H, GELBART T, WANG L, BEUTLER E: Regulation of hepcidin transcription by interleukin-1 and interleukin-6. Proc Natl Acad Sci USA 102: 1906-1910, 2005.

LINDNER J, MARUNA P, KUNSTÝŘ J, JANSA P, GÜRLICH R, KUBZOVÁ K, ZAKHARCENKO M, LINHART A: Hemodynamic instability after pulmonary endarterectomy for chronic thromboembolic pulmonary hypertension correlates with cytokine network hyperstimulation. Eur Surg Res 43: 39-46, 2009.

MARTÍNEZ ROSAS M: Cardiac remodeling and inflammation. Arch Cardiol Mex 76: S58-S66, 2006.

MARUNA P, LINDNER J, KUBZOVÁ K, KUNSTÝŘ J: Quantitative analysis of procalcitonin and cytokines after pulmonary endarterectomy. Prague Med Rep 109: 149-158, 2008.

MARUNA P, LINDNER J, KUNSTÝŘ J, PLOCOVÁ K, HUBÁČEK J: Plasma prohepcidin as a negative acute phase reactant after large cardiac surgery with a deep hypothermic circulatory arrest. Physiol Res 58: 827-833, 2009.

NEMETH E, VALORE EV, TERRITO M, SCHILlER G, LICHTENSTEIN A, GANZ T: Hepcidin, a putative mediator of anemia of inflammation, is a type II acute phase protein. Blood 101: 2461-2463, 2003.

NEMETH E, RIVERA S, GABAYAN V, KELLER C, TAUDORF S, PEDERSEN BK, GANZ T: IL-6 mediates hypoferremia of inflammation by inducing the synthesis of the iron regulatory hormone hepcidin. J Clin Invest 113: 1271-1276, 2004.

NEMETH E, GANZ T: Regulation of iron metabolism by hepcidin. Annu Rev Nutr 26: 323-342, 2006.

NiCOLAS G, CHAUVET C, VIATTE L, DANAN JL, BIGARD X, DEVAUX I, BEAUMONT C, KAHN A, VAULONT S: The gene encoding the iron regulatory peptide hepcidin is regulated by anemia, hypoxia, and inflammation. J Clin Invest 110: 1037-1044, 2002.

PAPANIKOLAOU G, TZILIANOS M, CHRISTAKIS JI, BOGDANOS D, TSIMIRIKA K, MACFARLANE J, GOLDBERG YP, SAKELLAROPOULOS N, GANZ T, NEMETH E: Hepcidin in iron overload disorders. Blood 105: 4103-4105, 2005.

PARK CH, VALORE EV, WARING AJ, GANZ T: Hepcidin, a urinary antimicrobial peptide synthesized in the liver. J Biol Chem 276: 7806-7810, 2001.

PIPERNO A, MARIANI R, TROMBINI P, GIRELLI D: Hepcidin modulation in human diseases: From research to clinic. World J Gastroenterol 15: 538-551, 2009.

ROSCOE A, KLEIN A: Pulmonary endarterectomy. Curr Opin Anaesthesiol 21: 16-20, 2008.

SWINKELS DW, GIRELLI D, LAARAKKERS C, KROOT J, CAMPOSTRINI N, KEMNA EH, TJALSMA H: Advances in quantitative hepcidin measurements by time-of-flight mass spectrometry. PLoS One 3: e2706, 2008.

TRUKSA J, PENG H, LEE P, BEUTLER E: Different regulatory elements are required for response of hepcidin to interleukin-6 and bone morphogenetic proteins 4 and 9. Br J Haematol 139: 138-147, 2007. 
VOKURKA M, KRIJT J, ŠULC K, NEČAS E: Hepcidin mRNA levels in mouse liver respond to inhibition of erythropoiesis. Physiol Res 55: 667-674, 2006.

VOKURKA M, LACINOVÁ Z, KŘEMEN J, KOPECKÝ P, BLÁHA J, PELINKOVÁ K, HALUZÍK M, NEČAS E: Hepcidin expression in adipose tissue increases during cardiac surgery. Physiol Res 59: 393-400, 2010.

WEISS G, GOODNOUGH LT: Anaemia of chronic disease. $N$ Engl J Med. 352: 1011-1023, 2005.

WRIGHTING DM, ANDREWS NC: Interleukin-6 induces hepcidin expression through STAT3. Blood 108: 32043209, 2006.

ZHANG AS, ENNS CA: Molecular mechanisms of normal iron homeostasis. Hematology Am Soc Hematol Educ Program 207-214, 2009. 